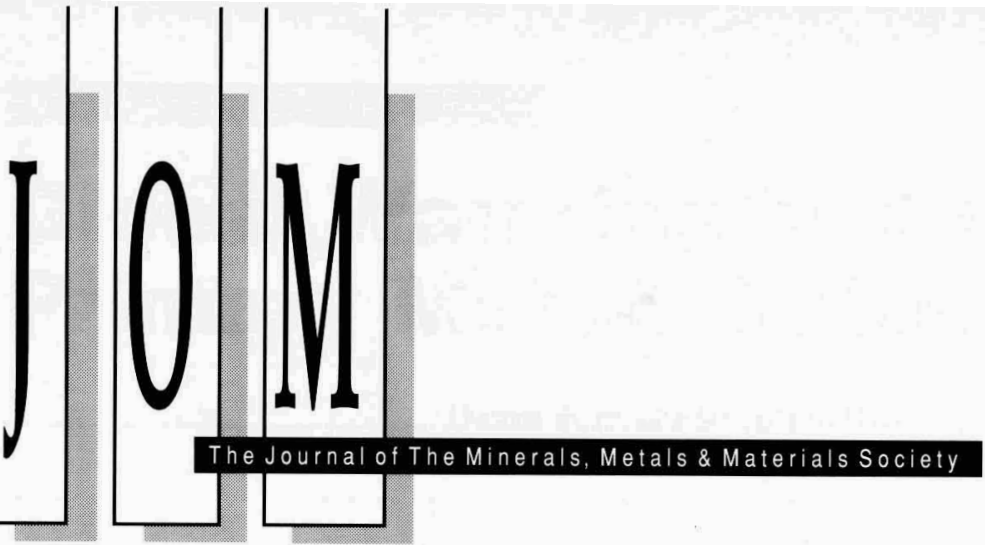

\title{
Global Warming and the Primary Metals Industry
}

David Forrest and Julian Szekely 


\title{
Global Warming and the Primary Metals Industry
}

\author{
David Forrest and Julian Szekely
}

Editor's Note: Global warming is the subject of a position paper being developed by an ad hoc committee of the American Institute of Mining, Metallurgical, and Petroleum Engineers. The paper, expected in early 1992, will attempt to provide an unbiased evaluation of the issues surrounding CO induced climate change. For more information, see the une 1991 edition of TMS News, page 42

This article is expanded from a unpublished presentation given at the TMS-sponsored Second International Symposium on Recycling of Metals and Engineering Materials, held October 28-31, 1990, in Williamsburg, Virginia.

Author's Note: It is inevitable that, as interest in the global warming problem increases, the specific role of the primary metals producers will be brought into question. We hope that this article provides some helpful perspectives.

The case for global warming due to anthropogenic sources of greenhouse gases is compelling, but its quantitative effects are still scientifically unproven. Today, the U.S. primary metals industry's carbon emissions account for slightly less than one percent of the global total. Further reductions are possible through the implementation of existing energy conservation measures, through more extensive recycling, and by the development and implementation of alternative processing technologies.

\section{INTRODUCTION}

The phenomenon of global warming and its consequences received widespread public attention and concern during the 1980s. The scientific community has made a considerable effort to study the situation, ${ }^{1-11}$ but there is still wide debate over how quickly the Earth's average atmospheric temperature is changing and what the consequences of that change will be. Nevertheless, the growing body of evidence indicates that human activities are causing some degree of global warming.

This article reviews the current knowledge of global warming, quantifies the relative contribution of the U.S. metals processing industry to this problem, and shows that recycling and alternative processing technologies can help to reduce carbon dioxide emissions.

\section{A GLOBAL WARMING PRIMER}

\section{The Greenhouse Effect}

The Earth's surface and lower atmosphere are kept warm by what is popularly known as the "greenhouse effect." Like the glass of a greenhouse, gases in the atmosphere raise the temperature by absorbing and re-radiating energy back toward the Earth's surface. The net energy balance of this process is zero: the amount of energy received from the sun $\left(340 \mathrm{~W} / \mathrm{m}^{2}\right.$ averaged over the
Earth's surface) is the sameas the amount radiated and reflected back to space (see Figure 1). The greenhouse effect makes the Earth's surface $33^{\circ} \mathrm{C}$ warmer than it would be otherwise. ${ }^{11,13}$ From space, the Earth would appear to be at an average temperature of $-18^{\circ} \mathrm{C}$. This is because long-wavelength radiation from the Earth's surface is absorbed by clouds and greenhouse gases, and much of that is re-radiated back toward the Earth, making the true surface temperature (obscured from space by the clouds and gases) a comfortable $15^{\circ} \mathrm{C}$ on average.

\section{Global Sources and Sinks of Greenhouse Gases}

The two largest contributors to the greenhouse effect are water vapor and carbon dioxide. Other gases, which contribute an additional $50 \%$ of the warming effect of carbon dioxide by itself, include methane, nitrous oxide, ozone, and the chlorofluorocarbons (CFCs). ${ }^{14}$

Trapped bubbles of air in Antarctic ice core samples provide records of atmospheric $\mathrm{CO}_{2}$ levels over long periods, and measurements at Mauna Loa, $\mathrm{Ha}$ waii, provide accurate data from 1958 to date. The carbon dioxide concentration reached a maximum of $300 \mu \mathrm{l} / 1$ about 130,000 years ago and fell to $200 \mu \mathrm{l} / 1$ at the height of the last glaciation, 20,00040,000 years ago. ${ }^{15}$ (The drop in $\mathrm{CO}_{2}$ was more likely a consequence of the ice age rather than a cause of it. Although the causes of ice ages are not fully resolved, one explanation is periodic variations in the Earth's tilt and orbit. As the Earth cooled, ice sheets grew and sea levels went down; nutrient runoff from newly exposed coasts increased phytoplankton productivity and trapped more $\mathrm{CO}_{2}$ in the ocean; carbon was also trapped under the advancing glaciers, in frozen ground, and in bogs. While not the primary cause, reductions in $\mathrm{CO}_{2}$ probably enhanced the cooling effects.)

From about 1,000 years ago until about 150 years ago, $\mathrm{CO}_{2}$ concentration was fairly constant at $280 \mu \mathrm{l} / 1$. Since then, $\mathrm{CO}_{2}$ levels have increased $25 \%$ (to over $350 \mu \mathrm{l} / \mathrm{l}$ ) due to human-related activities such as fossil fuel burning, natural gas flaring, cement production, cattle ranching, rice paddy agriculture, deforestation, mining, and organic matter changes in the soils. ${ }^{16,17}$ Similarly, methane concentrations have doubled in the last 200 years largely due to cattle and sheep ranching ( $43 \%$ of that increase) and rice paddies ( $34 \%$ of that increase)..$^{18}$

The burning of fossil fuel is the dominant source of carbon emissions result-

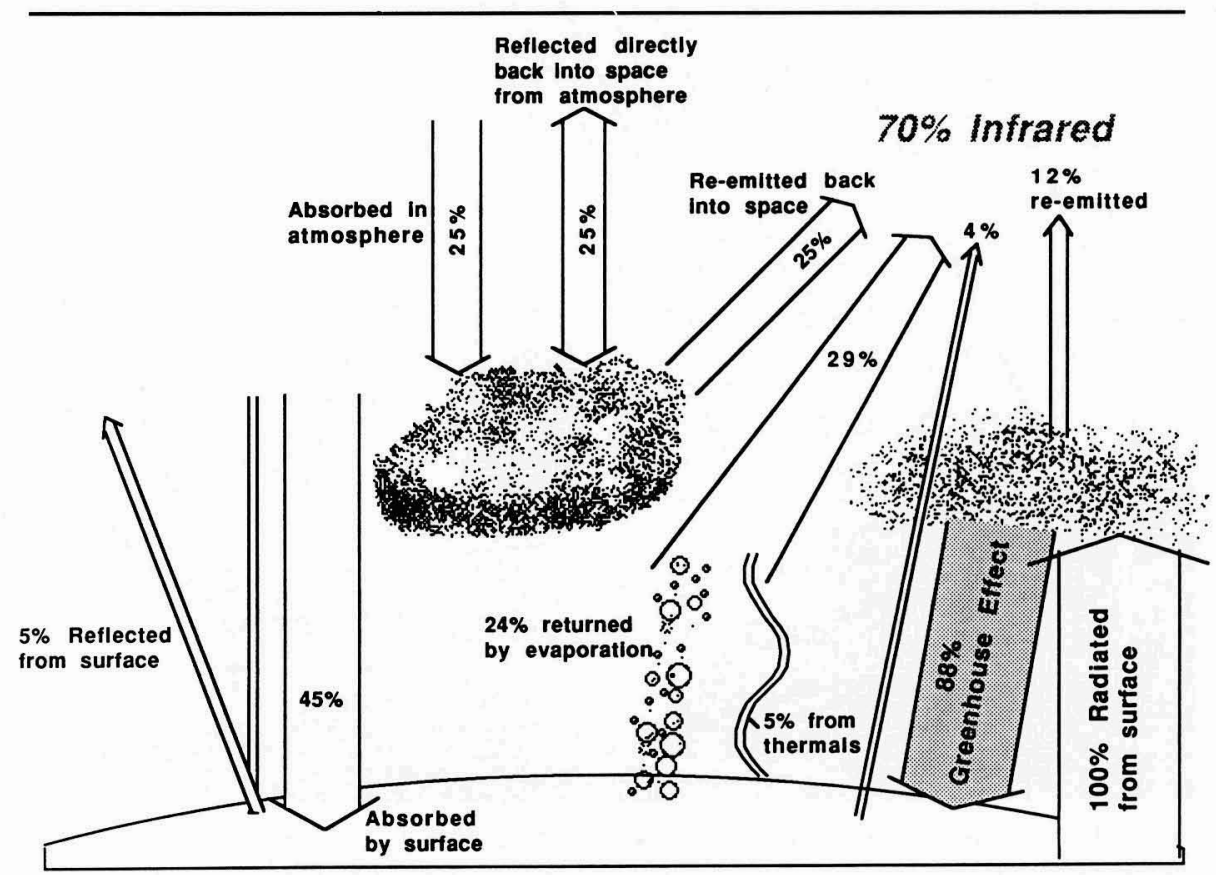

Figure 1. The solar radiation budget and the greenhouse effect. ${ }^{12}$ 


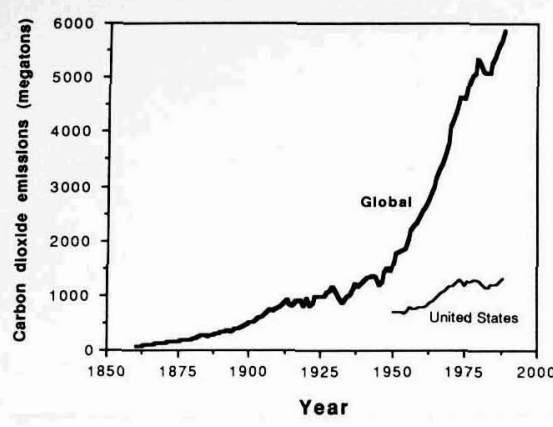

Figure 2. Global and U.S. carbon dioxide production from fossil fuels, cement manufacturing, and natural gas flaring. ${ }^{19,20}$

ing from human activities. Figure 2 shows the historical emissions of $\mathrm{CO}_{2}$ due to fossil fuel burning, cement production, and natural gas flaring. In 1984, $5.3 \mathrm{Gt}$ (billion metric tons) of carbon were released from fossil fuels and cement manufacture and $0.4-0.8 \mathrm{Gt}$ of carthe tropics. ${ }^{21}$ Of the fossil fuel carbon released between 1958 and 1983, 58\% has been retained by the atmosphere. ${ }^{22}$ The rest was assimilated by the oceans, the soil, and plant matter. It is important to realize that the fossil fuel carbon contribution is just a small fraction of the total carbon transfer between the terrestrial biosphere, the atmosphere, and the oceans (Figure 3). Nevertheless, this small relative contribution has the capacity to significantly alter the natural level of $\mathrm{CO}_{2}$ and the climate as well. bon were released from deforestation in

\section{Evidence of Global Warming}

There is wide agreement among scientists that greenhouse warming keeps the Earth's surface at its current temperature. There is some debate over the predicted increases in $\mathrm{CO}_{2}$, and there is considerable debate over the projected climatic changes resulting from those increases. Arrhenius seems to have been the first to calculate the temperature rise due to a doubling of $\mathrm{CO}_{2}$; he estimated a 4- $6^{\circ} \mathrm{C}$ increase in average temperature. ${ }^{23}$ Modern climate models predict an increase in average surface temperature of $1.5-4.5^{\circ} \mathrm{C} .{ }^{24,25}$ They also predict that, based on known $\mathrm{CO}_{2}$ emissions, the Earth should be about $1{ }^{\circ} \mathrm{C}$ warmer than it was 100 years ago. ${ }^{26}$ In fact it is about $0.5^{\circ} \mathrm{C}$ warmer, when surface temperature data are corrected for the "urban heat island" effect, ${ }^{12}$ so the models seem accurate to within about a factor of two.

There are many difficulties in developing good mathematical climate models, known as general-circulation models (GCMs), due in part to an incomplete understanding of the physical processes involved. ${ }^{15,27,28}$ To wit:

- We are currently unable to balance all the fluxes of the global carbon cycle over the past 200 years.

- We do not have a good understanding of ocean uptake and circulation of $\mathrm{CO}_{2}$.

- We do not have good estimates of the "biological pumping" con-

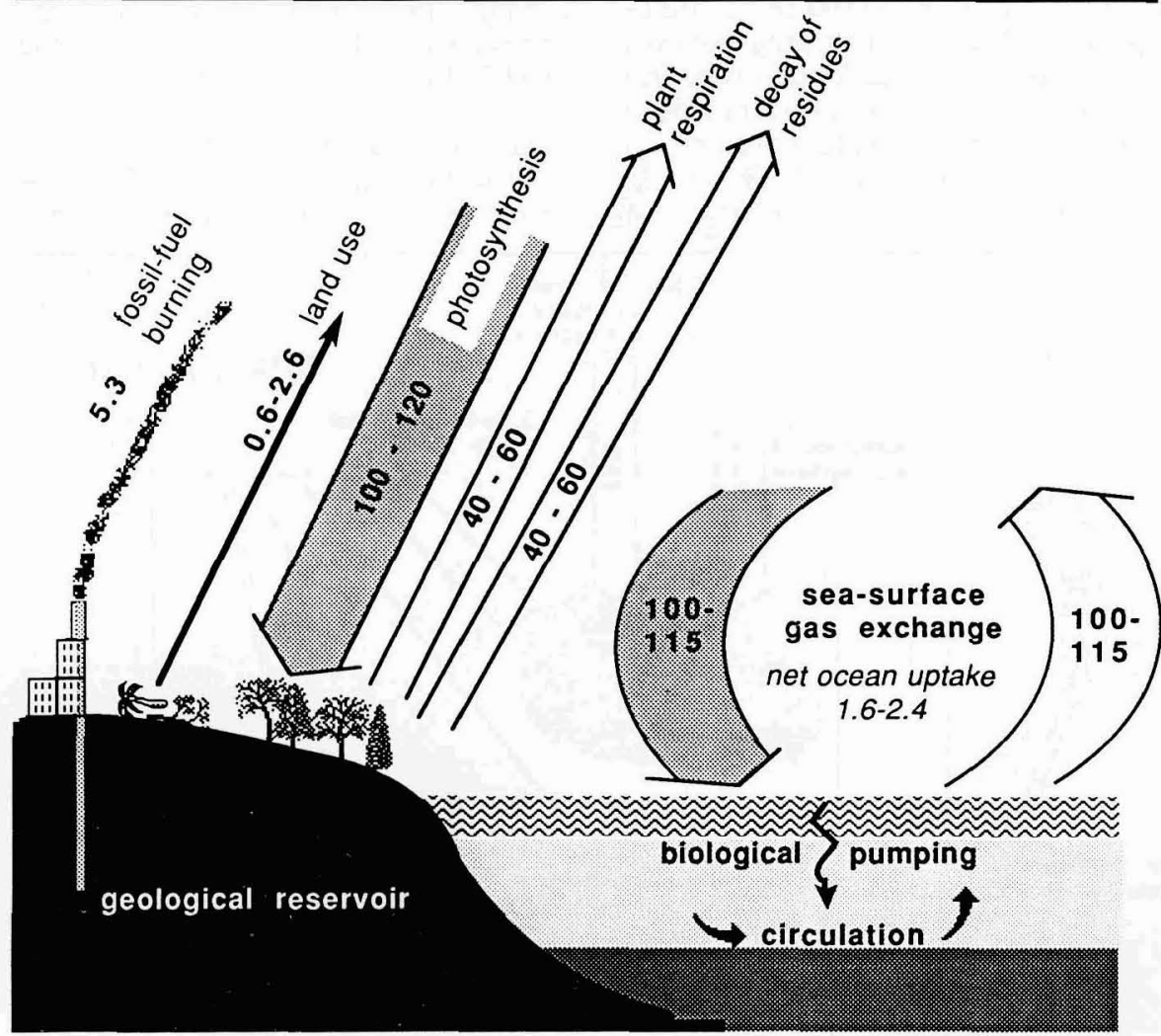

Figure 3. Anthropogenic carbon sources are small compared with the natural carbon fluxes, but only about half of the emissions are absorbed by the biosphere and the effect of a cumulative buildup over time is unknown. Shown are 1980 estimates in billions of tonnes of carbon per year. ${ }^{15}$ tribution in the oceans (when fecal pellets and dead organisms sink to deep waters).

- The effects of reduced sea ice at high latitudes (due to warming) are unknown-this may enhance biological production and increase ocean uptake of $\mathrm{CO}_{2}$.

- A recent study showed that photosynthetic organisms in seawater may produce up to twice the previously accepted value of dissolved organic compounds. At an estimated production rate of $4.3 \mathrm{Gt} / \mathrm{y}$, changes in this source (due to global warming) could significantly alter the calculated ocean-atmosphere $\mathrm{CO}_{2}$ exchange rate.

In addition, the models' grids are necessarily large because of the long computation times, so factors like cloudiness must be approximated using empirical parameters. ${ }^{29}$

Yet there are good reasons to have some degree of confidence in the climate models' predictions, despite the discrepancies and problems. Climate models have successfully verified theories or reproduced some historical weather patterns, ${ }^{12}$ including contemporary planetwide seasonal temperature patterns, a pattern of more intense monsoons in Africa and Asia 9,000-5,000 years ago, a dramatic cold spell in Western Europe called the Younger Dryas 11,000 years ago, and the temperatures on Mars (cold) and Venus (hot) due to the greenhouse effect. Additionally, a model has shown that the best explanation for the unusually warm temperatures of the Cretaceous period (about 100 million years ago, when alligators roamed at Arctic Circle latitudes) is greenhouse warming from much higher levels of $\mathrm{CO}_{2}$. Because of these successes, many researchers believe that the models can provide reasonable estimates of temporal and spatial variations of future climates, depending on the accuracy of assumptions about future $\mathrm{CO}_{2}$ emissions. ${ }^{30}$

The actual temperature data are somewhat ambiguous. Figure 4 shows that the average surface temperatures rose from 1860 to about 1945 , cooled from 1945 to about 1975, and then increased rapidly through the 1980 s (1990 was the warmest year on record). If anthropogenic sources are causing a global warming, there are other factors present which appear to mitigate that to some extent. Possible explanations for why the GCMs do not predict this include variation in solar output, volcanoes injecting more dust than is known, errors in modeling ocean effects, or coal combustion releasing $\mathrm{SO}_{2}$, which might nucleate droplets of sulfuric acid and increase the reflectivity of the atmosphere. ${ }^{26}$ Efforts to determine whether global warming is being caused by increasing $\mathrm{CO}_{2}$ have been unsuccessful- 


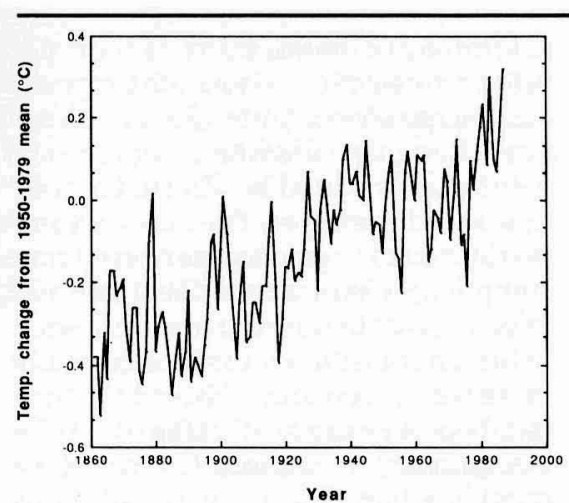

Figure 4. The variation of the Earth's surface temperature with time. ${ }^{13}$

the observed warming is statistically inseparable from natural fluctuations. ${ }^{31,32}$

In summary, many (but not all ${ }^{31,33-35}$ ) researchers feel that increased $\mathrm{CO}_{2}$ will significantly increase the Earth's surface temperature. The principal debates seem to be over these issues: How much will the temperature rise for a given increase in $\mathrm{CO}_{2}$ ? How quickly will that occur? How will a given temperature increase affect weather patterns? What actions should be taken given the present uncertainty in projections?

\section{Consequences of Global Warming and Policy Considerations}

The effects of global warming on climate patterns have been projected by several numerical models over the past 15 years. Most of the models do not simulate the transient effects of global warming; they increase the $\mathrm{CO}_{2}$ (usually by a factor of two) and let the model run to equilibrium. ${ }^{36}$ Taken together, the models show that global temperatures will rise $1.5-4.5^{\circ} \mathrm{C}$ over the next 50 years, which means that the planet will be warmer than at any time during the history of our species. ${ }^{24}$ While a few degrees may not seem like much, given the typical daily and seasonal variations, on average the Earth's temperature is extraordinarily constant. Several degrees change in the average constitutes a major change in climate; cool the Earth's average temperature by $9^{\circ} \mathrm{C}$ and you have a full-blown ice age.

The model of Manabe et al. predicted that both doubling and quadrupling $\mathrm{CO}_{2}$ levels would produce a summer dry zone in the North American grain belt and a moistureincrease in the monsoon belts. ${ }^{36}$ (Because they omitted some ocean heat transport factors, the time scale for these changes is probably 100 years rather than the projected several decades.) The reduced precipitation and higher temperature they predicted would severely strain water resources in the western United States; crop irrigation would be reduced, resulting in lower yields. ${ }^{37}$ Other models showed that, for $\mathrm{CO}_{2}$ doubling, European temperatures could increase by $2-6^{\circ} \mathrm{C}$ in the summer and by $4-16^{\circ} \mathrm{C}$ in the winter. ${ }^{24}$ One study by Manabe and Wetherald showed summer temperatures in the United States up to $8^{\circ} \mathrm{C}$ warmer. ${ }^{38}$ Oceans are projected to rise $0.3 \mathrm{~m} \pm 0.4 \mathrm{~m}$ by year 2100 due to global warming (note the wide error range in the projection), ${ }^{39}$ with possibly significant consequences for coastal regions. ${ }^{40} \mathrm{Higher}$ growth rates of plants under increased $\mathrm{CO}_{2}$ may help, as the plants will incorporate more carbon, but increased radiation due to ozone thinning (because of CFCs) may substantially reduce that benefit. ${ }^{41}$

Because of the uncertainties in the models and the lack of a statistically significant link between greenhouse gas emissions and global warming, some political leaders are hesitant to take steps that may prove costly. ${ }^{42-44}$ Other leaders, particularly in Germany, Sweden, and the Netherlands, are taking more active steps to reduce greenhouse gas emissions. ${ }^{42,45}$ James Burke, a historian and author who has been active in the debate on global warming, says it does not matter whether the greenhouse effect is actually occurring - as long as the consensus of scientific opinion says it will eventually occur, something should be done now to forestall it. ${ }^{46}$

\section{SOLUTIONS}

The cost of controlling carbon dioxide emissions using existing technologies could be hundreds of billions of dollars, ,,47 but reducing $\mathrm{CO}_{2}$ emissions by stepping up energy conservation measures could provide a cost savings. Energy conservation does not necessarily lead to lower product costs, so industries worldwide may not always take this path on their own accord. Economic solutions have therefore been proposed: financial incentives and disincentives, steep taxes on energy, modest taxes on energy, and an international market in emission permits. ${ }^{48}$

\section{Technological Solutions}

Systems able to remove $\mathrm{CO}_{2}$ from the atmosphere have been studied to varying degrees, and Edmonds etal. ${ }^{49}$ provide an excellent summary. Examples are absorption and stripping of $\mathrm{CO}_{2}$ using liquid solvents, burning fuel to $\mathrm{CO}$ then combining with a non-fossil hydrogen source to form liquid and gaseous fuels, burning oxygen and carbon diluted with recycled $\mathrm{CO}_{2}$ (resulting in concentrated $\mathrm{CO}_{2}$ that can be recovered or disposed of), electrochemical decomposition of $\mathrm{CO}_{2}$, and photosynthetic fixation of $\mathrm{CO}_{2}$ in plants and trees. Disposal methods include deep ocean dumping (environmental impact unknown), burying in the Earth as solids or in spent wells as a gas, ${ }^{9}$ and trapping carbon in seaweed or salt desert plantations. ${ }^{50}$

Long-term climate scenarios (e.g., 50 to 100 years) are based on best estimates of population growth, the resulting energy requirements for that population, and the anticipated mix of energy sources. These projections are primarily based on current trends and do not account for radical technological advances such as the self-replicating molecular machines (often referred to as nanotechnology) described by Drexler. ${ }^{51-57}$ Like biological systems, nanomachines could remove $\mathrm{CO}_{2}$ directly from the atmosphere in a massively parallel distributed manner, but with much greater flexibility as to how the atoms are rearranged (carbides and diamond). Before committing hundreds of billions of dollars toward mitigation technologies - in order to avert or delay a climate disaster 50 years in the future-we should assess whether such a technology could mature in 20-30 years and solve the problem more cheaply, cleanly, and effectively. Although one should never assume that future technologies can solve today's problems, it is possible to make engineering projections from known physical laws and estimate bounds on system capabilities. ${ }^{58}$ While some of these engineering calculations have already been made for nanotechnology, an authoritative time frame assessment is still lacking.

\section{Financial Incentives and Disincentives}

Financial incentives for energy conservation have been widely implemented at both the state and federal levels for some time. On the whole, they have not been effective for a variety of reasons. As $\mathrm{Hu}$ points out, ${ }^{59}$ the effects of the federal legislative programs (e.g., the National Energy Act of 1978 and the Crude Oil Windfall Profits Tax Act) have conflicted with each other, generally canceling out.

Norman Dean has analyzed the effectiveness of various state financial incentive programs for increasing industrial energy efficiency ${ }^{60}$ Raising energy prices appears to be the best incentive, since this leaves all the investment decisions up to the business, but large price increases would be met with heavy political opposition; also, states must account for the resulting hardships placed on citizens as well as marginal businesses. State financial incentives, although politically more palatable, again did not seem to be effective in practice. These included tax subsidies, direct subsidies, loans, bond financing programs, and state credit corporations. One study of various economic incentives and financing options to stimulate energy conservation ${ }^{61}$ found that investment tax credits and cost sharing were the most helpful tactics for metal producers.

A final point on incentives is that different tactics may be needed for different kinds of metal producers. Thealumi- 
num companies already devote a large fraction of their R\&D efforts toward energy conservation, while the steel companies have historically focused more on quality control and new products. ${ }^{62}$ The latter should therefore benefit more from increased support for energy R\&D.

\section{Taxes on Energy}

The underlying philosophy behind carbon emission or energy taxes is that current energy prices do not reflect the hidden costs to the environment, so an effective solution must somehow impose those hidden costs (see, for example, Reference 63). Steep taxes on energy consumption may be effective but could cause economic hardships and may therefore be rejected by many nations. A modest tax - with the revenues directed toward energy conservation measures, finding replacements for CFCs, and reforestation-may be more practical.

Some of those who have studied global warming advocate measures to improve energy efficiency as one method to reduce carbon dioxide emissions, since it "usually makes economic sense" 64 to implement those measures anyway.
Unfortunately, if energy prices are artificially low (i.e., if prices do not reflect costs to the environment), economic analysis may show that it does not pay to implement some conservation measures. $\mathrm{Hu}^{65}$ studied the economics of three different energy conservation measures in the copper industry: using recycled scrap, flash smelting, and retrofitting reverberatory smelters with oxygen lances. His analysis showed that the product cost would increase in all three cases. Under 1974 price structures, the energy prices would have had to double to achieve economic breakeven. Such a marked increase due to increased taxes would severely disrupt the world economy, and efforts to enforce this internationally would therefore probably fail.

A less radical energy tax has been proposed by physicist JoséGoldemberg, Brazil's secretary of state for science and technology. ${ }^{66}$ He believes that a worldwide levy of $\$ 1$ per barrel of oil equivalent or $\$ 6$ per tonne of coal equivalent, which would generate about $\$ 50$ billion per year, could be used to finance the following measures to reduce greenhouse gas emissions: the phase-out of

Table I. 1968 and 1985 Energy Consumption and Carbon Emissions of U.S. Primary Metals Manufacturing Sector

\begin{tabular}{|c|c|c|c|c|}
\hline Quantity & Electricity & Coal & Natural Gas & Oil \\
\hline$\overline{1968 \text { Energy Consumed (PJ)* }}$ & 454 & $\overline{2,992}$ & 910 & $\overline{322}$ \\
\hline 1985 Energy Consumed (PJ) ${ }^{\dagger}$ & 506 & 1,191 & 727 & 53 \\
\hline 1968 Carbon Released $(\mathrm{Mt})^{\ddagger}$ & 25.9 & 71.2 & 12.5 & 6.2 \\
\hline 1985 Carbon Released $(\mathrm{Mt})^{\ddagger}$ & 26.2 & 28.4 & 10.0 & 1.0 \\
\hline
\end{tabular}

\section{* Data taken from Reference 67.}

+ Data taken from Reference 68 .

† Based on conversions in Reference 69, and relative contributions of coal, oil, and gas to electricity generated in Reference 70 .

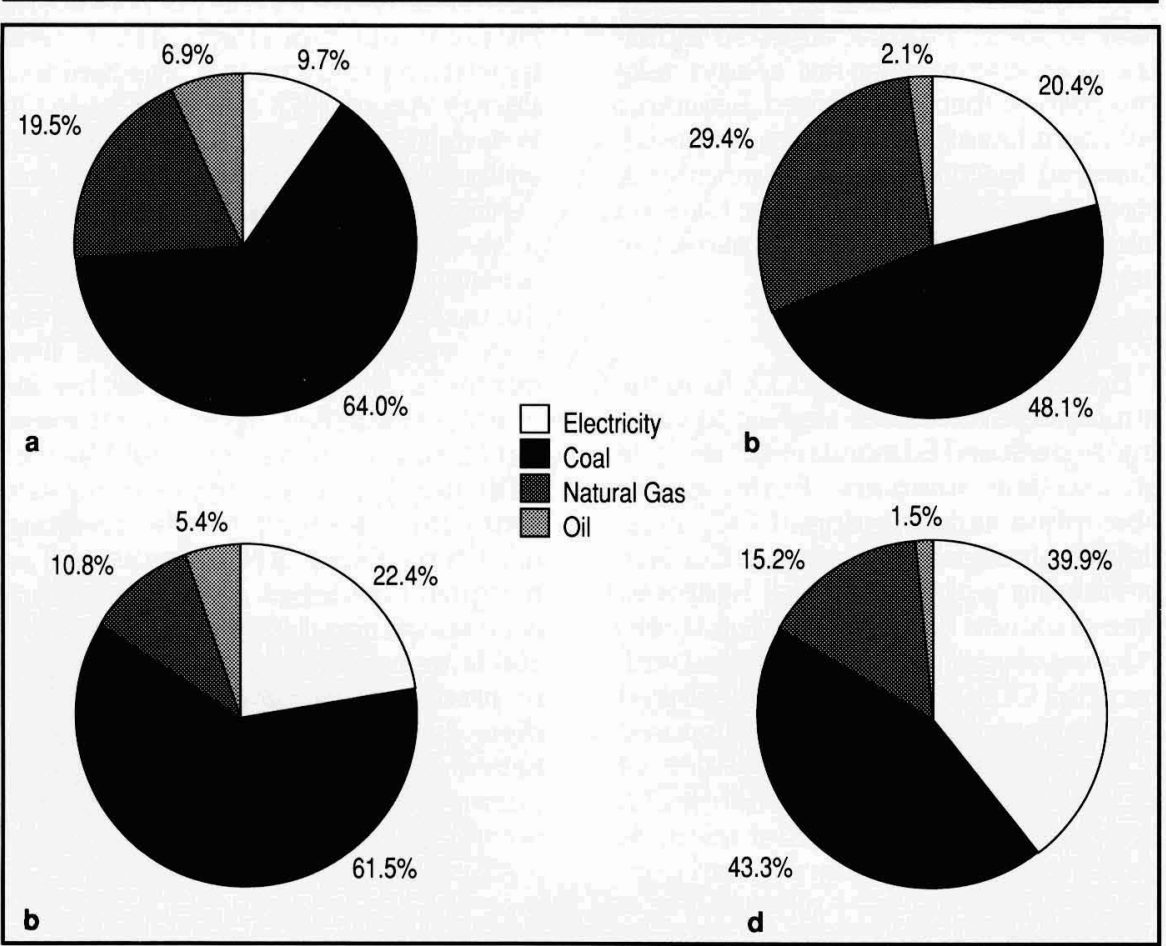

Figure 5. Graphs showing the change in the U.S. primary metals industry's energy consumption and carbon emissions from 1968 to 1985. (a) Energy consumption in 1968, 4.678 exajoules (EJ). (b) Energy consumption in 1985, 2.477 EJ. (c) Carbon emissions in 1968, 115.8 Mt. (d) Carbon emissions in 1985, 65.6 Mt. chlorofluorocarbons ( $\$ 700$ million per year), reforestation ( $\$ 15$ billion peryear), and energy conservation ( $\$ 30$ billion per year). Roughly half of the energy conservation funds would be directed to lessdeveloped countries. The tax is not primarily meant to discourage energy consumption; it is meant to "be a fair and effective way to raise the money needed to fund a transition into an ecologically more benign economy." Based on these numbers, we estimate that the cost to the U.S. primary metals industry would be roughly $\$ 300$ million per year. This turns out to be about $1 \%$ of the $\$ 30$ billion which would be available for energy conservation, roughly the same percentage as the global carbon emissions by the industry. (We are not sure how much of that amount would be made available to the industry under Goldemberg's plan.)

\section{Trading Carbon Equity Units}

A somewhat different approach has been endorsed by the Brookings Institution $^{48}$ and Burke. ${ }^{46}$ The Brookings Institution recommendation would give each nation a certain number of carbon equity units, based on projections of population and future economic activity. As nations burn carbon, they use up their units. When they run out, they must purchase additional units from other nations (Third World nations will have an excess). Burke's preference, based on a 1989 Dutch government report, is similar, except that instead of cash the carbon units buyers must trade technology. This will allow the less-developed nations to leapfrog inefficient technology, purchase highly efficient systems, and power them with renewable energy sources.

\section{GLOBAL WARMING AND THE METALS INDUSTRY}

\section{The Metals Industry's Contribution to the Greenhouse Effect}

It is convenient to lump fossil fuel burning into one combined category, so the data on human contributions to atmospheric carbon are usually presented in this manner. $15,19,22$ For this study, we sought to quantify the relative contribution of the U.S. metals processing industry to carbon emissions, so we developed the data in a different manner using some of the same sources.

Figure 5 shows the contribution for 1968 and 1985, broken out by energy source. (Industry-wide data, shown in Table I, were readily available for these particular years and were used to develop the graphs in Figure 5.) Overall, the gross energy consumption of the primary metals industry was reduced $53 \%$ between 1968 and 1985. An even greater reduction (57\%) in carbon emissions was realized, aided by an $11 \%$ decrease in the amount of carbon released per unit of electricity consumed. In 1968 the U.S. primary metals sector 
added $115.8 \mathrm{Mt}$ of carbon to the atmosphere, $2.7 \%$ of the global total; in 1985 that dropped to $65.6 \mathrm{Mt}$-about $0.8 \%$ to $1.0 \%$ of the global total.

Table II provides a more detailed accounting of carbon sources. Carbon emissions from primary steel dropped $50 \%$, due to three major factors:

- A 32\% reduction in total steel output (22 Mt carbon).

- A doubling in electric arc furnace (EAF) steel production from 15.4 $\mathrm{Mt}$ to $30.2 \mathrm{Mt}$ steel (4 Mt carbon); this displaced some basic-oxygen furnace (BOF) and open-hearth steel production.

- The balance (7.7 Mt carbon) is presumed to be due to energy conservation measures and improvements in operating efficiency, principally blast furnace operations, continuous casting, direct charging and rolling of ingots without cooling, and waste heat recovery. ${ }^{78}$

Carbon emissions from aluminum and copper processing were reduced by $36 \%$ (10.7 Mt) from 1968 to 1987 despite production increases of $44 \%$ for aluminum and $15 \%$ for copper, due to:

- Reduced use of coal (11 Mt carbon).

- Greater use of recycled aluminum scrap, from $20 \%$ to $30 \%$ of total shipments $^{79}$ (1.5 Mt carbon).

- An $11 \%$ reduction in the amount of carbon emitted per unit of electricity generated from fossil fuels (1.2 Mt carbon).

- Other efficiency improvements ( 7 Mt carbon, although this is difficult to evaluate because of uncertainties in the mix of hydropower and fossil-fuel electricity consumed for aluminum processing).

These numbers reflect the metals industry's successful continuing efforts to improve operating efficiency. These efforts are well-documented ${ }^{80,81}$ and include the development of the Alcoa smelting process $(30 \%$ less energy per tonne), ${ }^{82}$ the use of forced convection in aluminum reverberatory furnaces (25\% less energy), ${ }^{83}$ improvements in automated control and improved design of aluminum reverbatory furnaces ( 25 $30 \%$ less energy), ${ }^{84,85}$ the use of prebaked anodes in aluminum reduction cells, ${ }^{86}$ adoption of the Asarco shaft furnace for copper cathode melting (35\% less energy), ${ }^{87}$ the development of the flash smelter for copper ( $60 \%$ less energy than a reverbatory furnace), ${ }^{88}$ continuous casting of steel (5.5\% less energy), ${ }^{86} \mathrm{im}$ provements in electric arc furnaces for steelmaking (water-cooled roof and sidewall panels, oxygen lancing, foaming slag practices, and high-power, longarc operation), ${ }^{89,90}$ increased efficiency of steel reheat and annealing furnaces, ${ }^{91}$ and dry quenching of coke. ${ }^{91}$

Further energy savings are possible since materials processes use much more energy than dictated by their thermodynamic minimum values (by a factor of about two for steel and about three for aluminum). ${ }^{92}$ We should remark here that the energy consumption involved in metals production may vary quite widely from country to country, even when seemingly similar technologies are involved. Table III shows that the energy consumed per tonne produced varies by nearly a factor of two among Western nations. Here is an important caveat to this data from its source: ${ }^{3}$

This industry's structure in any particular country is determined not solely by the number of joules required to produce a ton of steel but is related to local conditions, and specifically to the availability and cost of various types of energy.

The different production routes require different forms of energy, and it is the relative delivered costs of the various types of energy which determine the most economical process in a particular location. Hence a higher energy consumption does not automatically imply that a particular country's industry is inefficient or uneconomic.

The latter observation points toward a solution for global warming which involves economic pressures favoring a more thermodynamically efficient industry. This would be most effective in the least "efficient" countries toward the bottom of the list in Table III, and possibly also in the Soviet Union as it converts to a market-based economy. Efficiency improvements in the People's Republic of China, however, would probably require a political mandate.

Table II. Carbon Released by Sectors of the U.S. Primary Metals Processing Industry Weight of Carbon Released (Mt)

Factors Causing Carbon Release

Global

Fossil Fuel Burning and Cement Manufacture

Deforestation and Other Land Use

United States

Fossil Fuel Burning

5,680

$600-2,600$

20

15

20

3,596

$1,100-1,800$

20

1,258

20

\section{Steel Production}

Crude Steel Production

Coal Consumption

Blast Furnace Limestone

Natural Gas Consumption

Fuel Oil Consumption

Purchased Electricity* Subtotal
80.9

$20.5-25.0$

1.0

3.6

0.45

7.3

$32.9-37.4$

$\begin{array}{cc}118.8 & 73 \\ 55.4 & 73 \\ 2.4 & \\ 2.3 & 73 \\ 1.8 & 73 \\ 6.9 & \end{array}$

Aluminum and Copper Production

Primary and Secondary $\mathrm{Al}$
Primary and Secondary $\mathrm{Cu}$
Coal Consumption
Natural Gas Consumption
Fuel Oil Consumption
Purchased Electricity*
Subtotal

$\begin{array}{cc}5.33 & 76 \\ 2.04 & 76 \\ 2.5-3.0 & 74,75 \\ 6.3 & 75 \\ 0.57 & 75 \\ \sim 9.5 & \end{array}$

3.69

1.78

13.9

4.0

2.3

$18.9-19.4$
* Using factors of $5.082 \times 10^{-8} \mathrm{~kg}$ carbon per joule electricity (1987) and $5.702 \times 10^{-8} \mathrm{~kg}$ carbon per joule electricity (1968). The 1987 number is from References 70 and 77, and the 1968 number is from References 70 and 73 . Self-generated electricity is no counted, since purchased oil, coal, and gas is already counted, and self-generated hydropower would not emit carbon.

\begin{tabular}{|c|c|c|c|c|c|}
\hline \multirow[b]{2}{*}{ Nation } & \multirow{2}{*}{$\begin{array}{c}1985 \\
(G J / \text { tcs })^{*} \\
\end{array}$} & \multirow{2}{*}{$\begin{array}{c}1980-1985 \\
\text { Change (\%) } \\
\end{array}$} & \multicolumn{3}{|c|}{ Processes Used in $1985(\%)$} \\
\hline & & & $\mathrm{BF} / \mathrm{BOF}$ & EAF & Other \\
\hline Spain & 15.5 & -17.8 & 39 & 61 & 0 \\
\hline Netherlands & 17.6 & -9.6 & 100 & 0 & 0 \\
\hline Japan & 17.7 & -9.3 & 71 & 29 & 0 \\
\hline Italy & 18.2 & -3.9 & 48 & 52 & 0 \\
\hline Sweden (1984) & 18.9 & -25.6 & 48 & 52 & 0 \\
\hline Luxembourg & 19.2 & -11.7 & 100 & 0 & 0 \\
\hline Brazil & 20.6 & Not Avail. & 72 & 25 & 3 \\
\hline Finland & 20.7 & +0.7 & $8 \overline{3}$ & 10 & 7 \\
\hline Austria & 20.8 & -8.5 & 99 & 1 & 0 \\
\hline United Kingdom & 21.2 & -9.4 & 72 & 28 & 0 \\
\hline Canada & 21.3 & -7.0 & 86 & 14 & 0 \\
\hline Belgium & 21.4 & -3.4 & 93 & 7 & 0 \\
\hline West Germany & 21.6 & -3.6 & 82 & 18 & 0 \\
\hline United States & 22.3 & -13.6 & 59 & 33 & 8 \\
\hline Australia & 22.4 & -10.6 & 99 & 1 & 0 \\
\hline France & 22.4 & -7.8 & 82 & 18 & 0 \\
\hline South Africa & 29.0 & -7.7 & 69 & 26 & 5 \\
\hline Soviet Union ${ }^{+}$ & $\sim 30$ & - & - & - & 52 \\
\hline China $^{+}$ & 52.5 & - & - & - & - \\
\hline
\end{tabular}

* tcs-tonnes of crude steel.

+ The statistics for the Soviet Union and China are from Reference 94. 


\section{Scrap and Energy}

If one looks at the published numbers for energy consumption in materials processing operations, there is little doubt that there are dramatic benefits to recycling (secondary production) versus producing metal from ore (primary production). The data in Table IV show energy reductions of $61 \%$ to $94 \%$ when processing scrap instead of ore. This corresponds directly to reductions in carbon dioxide emissions.

When analyzing recycling benefits, it is important to make some distinctions regarding the type of scrap. Home scrap is the waste produced within a fabrication plant:ingotdiscard, risers, shearings and trimmings, rejected material, and so on. It is recirculated within the plant and rarely shows up in published statistics. New scrap (also called "prompt" scrap) is generated by the users of semifinished steel; it includes turnings, borings, trimmings, and rejected material. Old scrap (also called "obsolete" scrap) is generated from products that have completed their useful life cycle: aluminum cans, steel rails, automobiles and farm equipment, dead batteries, structural members, etc. The data in Table IV are per tonne of output, so it includes the fuel used to recirculate the home scrap (up to $50 \%$ of total throughput). ${ }^{96}$ Kusik and $\mathrm{Kenahan}^{97}$ estimated that one-third of the raw steel produced was recycled as home scrap in 1978. Current numbers are probably much lower due to the increased use of continuous casters.

Chapman and Roberts ${ }^{8}$ have analyzed the interplay between resources and fuel consumption. Figure 6 is a simple material flowsheet which summarizes an important point-generating and recycling home scrap and new scrap does not decrease the amount of raw ore required to satisfy the demand for a product. Only the generation of old scrap can reduce that amount. Furthermore, recirculating new and home scrap

\begin{tabular}{|c|c|c|c|c|}
\hline \multirow[b]{2}{*}{ Metal } & \multicolumn{2}{|c|}{ Primary Production } & \multicolumn{2}{|c|}{ Secondary Production } \\
\hline & Assumptions & $(\mathrm{GJ} / \mathrm{t})$ & $(\mathrm{GJ} / \mathrm{t})$ & Assumptions \\
\hline Steel & $\begin{array}{l}\text { Average production in } \\
\text { basic oxygen furnace }\end{array}$ & 31.1 & 8.7 & $\begin{array}{l}100 \% \text { scrap in electric } \\
\text { arc furnace }\end{array}$ \\
\hline \multirow[t]{2}{*}{ Copper } & $1 \%$ ore (best) & 91.0 & 13.0 & High-grade scrap \\
\hline & $0.3 \%$ ore (worst) & 184.0 & 37.0 & Low-grade scrap \\
\hline Aluminum & From bauxite & 270 & 16.5 & Average scrap \\
\hline Zinc & $5 \%$ ore & 61 & 24.0 & Average scrap \\
\hline Lead & $2 \%$ ore & 39 & 9.0 & Average scrap \\
\hline Titanium & From beach sands & 430 & 140 & Includes refining alloys \\
\hline
\end{tabular}

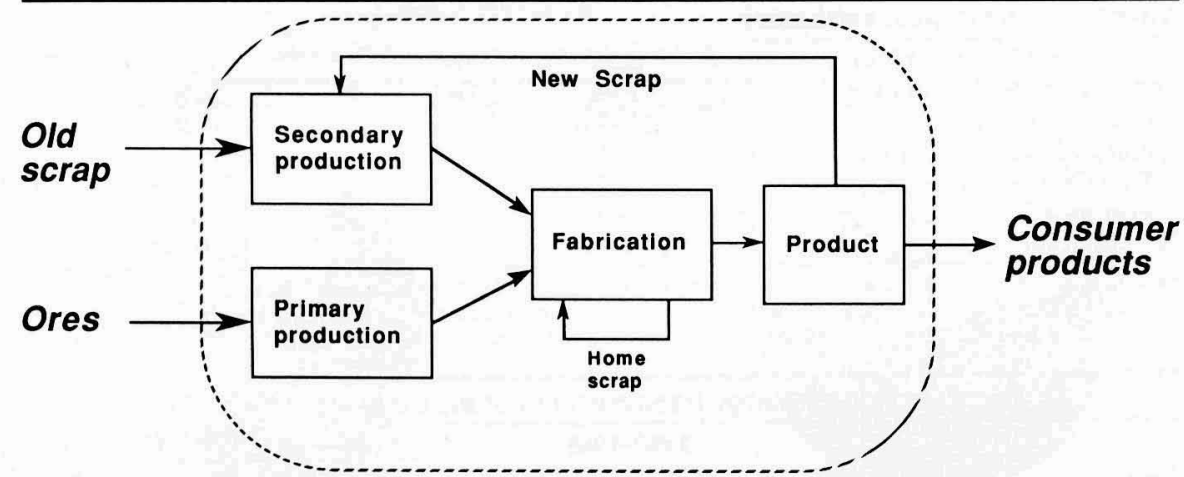

Figure 6. A diagram showing that the generation of new scrap does not reduce the demand for raw materials. ${ }^{98}$

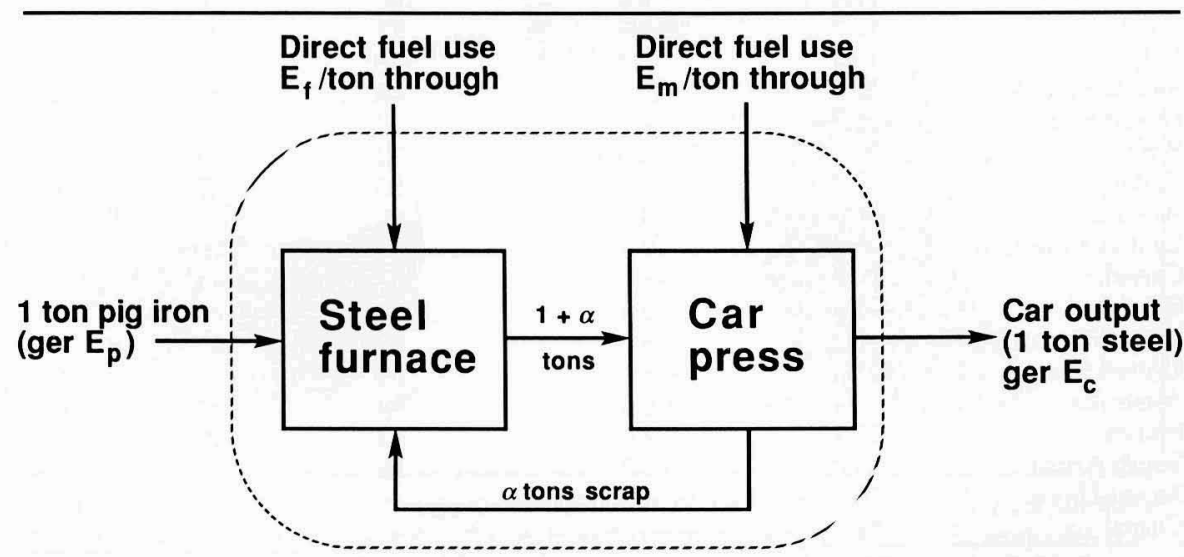

Figure 7. A hypothetical system with steel producer and auto manufacturer. The recirculating scrap increases fuel use but does not affect the amount of pig iron per car. ${ }^{98}$

increases the energy consumed per unit product. In Figure 7, this concept is applied to the GER (gross energy requirement) to produce a car:

$$
\mathrm{GER}=\mathrm{E}_{\mathrm{c}}=\mathrm{E}_{\mathrm{p}}+(1+\alpha)\left(\mathrm{E}_{\mathrm{f}}+\mathrm{E}_{\mathrm{m}}\right)
$$

where $E_{c}$ is the energy required to produce the car, $\mathrm{E}_{\mathrm{p}}$ is the energy required to produce the pig iron input into the steelmaking furnace, $E_{f}$ is the energy consumed in the steelmaking furnace, $E_{m}$ is the energy required to manufacture the car, and $\alpha$ is the tonnage of recirculated scrap per unit output. Chapman and Roberts point out that it is possible that both the steel producer and the car manufacturer could conclude that it would be cheaper to invest in equipment which uses or produces more scrap, but that these decisions would actually result in a higher GER per car. ${ }^{99}$

The analysis of mixed primary and secondary production is only slightly more complex. Figure 8 illustrates this case. The GER is given by

$$
\begin{gathered}
\text { GER }=f(1+\alpha)(1+\beta)\left(F_{m m}+F_{s}\right)+ \\
(1-f)(1+\alpha)(1+\beta) F_{s s}+ \\
(1+\beta) F_{f}+F_{p}
\end{gathered}
$$

where $f$ is the fraction of product from primary production, $(1-f)$ is the fraction of product from secondary production, $\alpha$ is the tonnes of home scrap per tonne of output, $\beta$ is the tonnes of new scrap per tonne of output, and $F_{x}$ is the fuel requirement for process $x$ (the processes are defined in Figure 8).

Equation 2 also shows that the more home and new scrap, the higher the GER. Since the fuel requirement for primary production $\left(F_{m m}+F_{s}\right)$ is much greater than that for secondary production $\left(\mathrm{F}_{\mathrm{ss}}\right)$, the GER is very sensitive to the mix of primary and secondary production. This is not to say that recycling home and new scrap is useless-throwing it away would only increase the fraction of product made from ore (f), increasing the GER even more.

Thus, if all stages of the process are designed to generate less home and new scrap, then the total amount of energy per unit product goes down, and so does the cost, and so do the carbon dioxide emissions. Likewise, increasing the availability of old scrap can reduce dependence on high-GER primary production. Old scrap availability is limited by the efficiency of scrap recovery (sometimes as low as 35\%) and depends on consumption growth versus product lifetime (slower growth and shorter lifetimes increase availability). Another point is that product design changes can improve recovery efficiency, but the changes may increase the product manufacturing cost while the scrap recoverer and the metals producer reap the benefits of the increased efficiency. While these resource and energy issues may seem basic to those in the recycling 


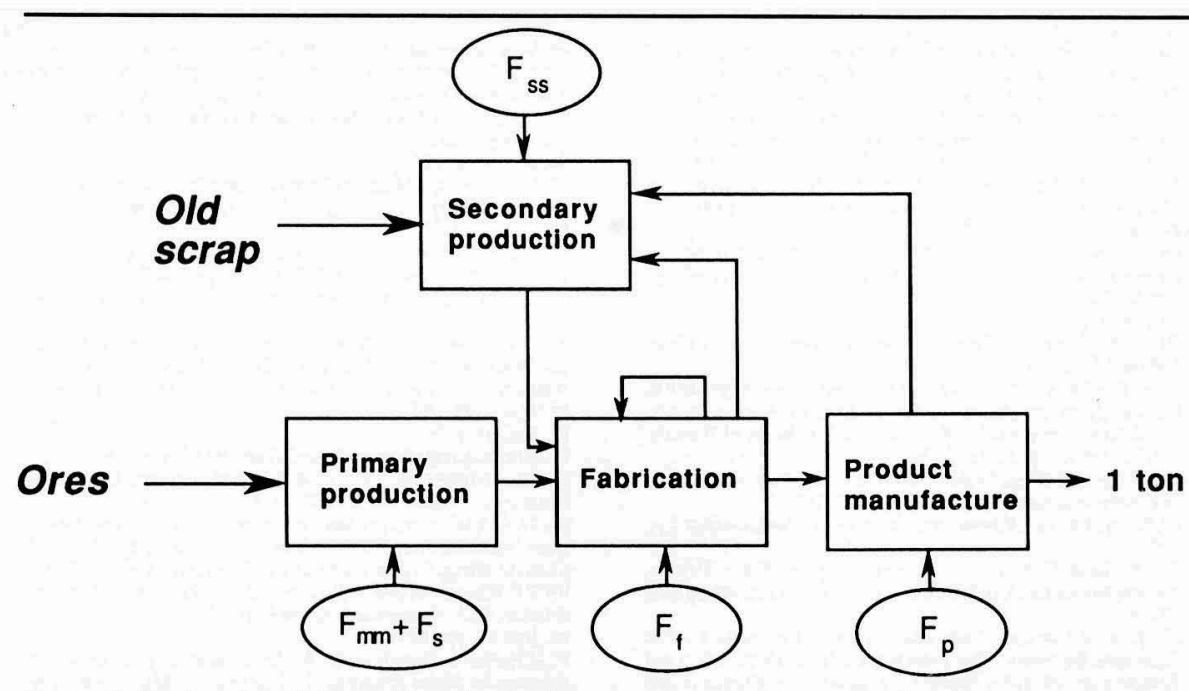

Figure 8. Fuel and metal flows for mixed primary and secondary production. ${ }^{98}$

community, it is important to reiterate them here since they are rarely mentioned in the global warming literature.

\section{The Estimated Benefits of Recycling to Carbon Emissions}

Given a known amount of unrecovered old scrap, it is possible to estimate how much carbon emissions would be reduced if this old scrap were recovered and processed (thereby reducing the demand for ore). These estimates ignore the practical problems like sufficient capacity to process all the old scrap and

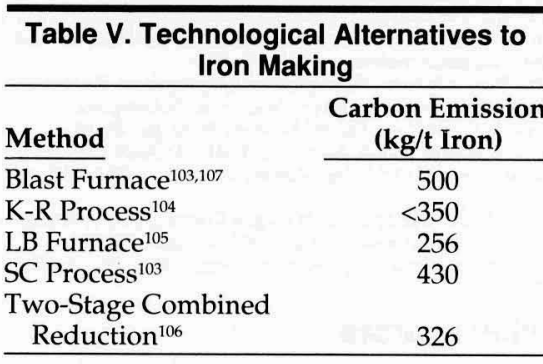

Note: Values shown are derived from carbon input or electrical energy and fuel input; they do not include electrode consumption or the energy associated with refractories, forming. As is customary in this type of analysis, the energy contribution (and therefore the carbon emission contribution) of scrap is assumed to be zero.

Table VI. Technological Alternatives to Steelmaking

\section{Method}

Electric Arc Furnace Basic Oxygen Furnace C-FFOX ${ }^{109}$

$\mathrm{K}(\mathrm{M}) \mathrm{S}^{110}$

* Based mostly on the electricity consumption value in Reference 97, conversions in Reference 69, and the relative contributions of coal, oil, and gas to electricity generated in Reference 70.

+ Based on $500 \mathrm{~kg}$ carbon per tonne hot metal and $31.4 \%$ scrap charge plus some miscellaneous fuel and electricity.

$\ddagger$ Depending on type of coal used and degree of postcombustion, and assuming $100 \%$ scrap charge.

Note: Values shown are derived from carbon input or electrical energy and fuel input; they do not include electrode consumption or the energy associated with refractories, electrodes, fluxes, scrap handling, oxygen, casting, carbon emission contribution) of scrap is assumed to be zero. sufficient markets for old scrap products which have limited applications because of higher contaminant levels.

In the case of aluminum, Chapman and Roberts ${ }^{100}$ give a value of $35 \%$ recovery efficiency. Their figures for recovery of packaging may be low, given that recycling of cans is now up to $55 \%,{ }^{101}$ so we will assume a recovery efficiency of $50 \%$. This also gives a more conservative (minimum) estimate for $\mathrm{CO}_{2}$ emission reduction. In 1988, $1 \mathrm{Mt}$ of old scrap was recovered and processed to yield about $911 \mathrm{kt}$ of aluminum metal. Fifty percent recovery efficiency means that an additional 911 kt could have been recovered, displacing that same amount of metal produced from raw ore. We estimate a savings of $2.75 \mathrm{t}$ of carbon per tonne of old scrap product substituted for raw ore product, which translates to $2.5 \mathrm{Mt}$ of carbon potentially saved (in 1988) with $100 \%$ recovery.

In the case of steel, in the United States there is an extremely high reserve of scrap-Fruehan ${ }^{90}$ quoted a figure of over $750 \mathrm{Mt}$ of available recoverable scrap, with $30 \mathrm{Mt}$ added to inventory in 1983. If one takes the latter as the figure for displacing BOF steel with EAF steel, at an estimated savings of $0.26 \mathrm{t}$ carbon per tonne of EAF steel substituted for BOF steel, there is the potential to reduce carbon emissions by at least 7.8 Mt in a year. Tapping into the $750 \mathrm{Mt}$ reserve would yield even greater reductions. Once again, these estimates are first attempts to quantify the potential for reducing $\mathrm{CO}_{2}$ emissions through recycling, while ignoring the practical difficulties in implementation.

\section{CAN ALTERNATIVE TECHNOLOGIES HELP?}

In iron making, steelmaking, and aluminum processing, new process technologies have the potential to significantly reduce energy consumption and, therefore, $\mathrm{CO}_{2}$ emissions. For aluminum, this would involve the use of carbon to directly reduce $\mathrm{Al}_{2} \mathrm{O}_{3}$ to aluminum metal. Although the ongoing work in this area is promising, ${ }^{102}$ the research is not sufficiently advanced to make accurate projections on potential reductions in $\mathrm{CO}_{2}$ emissions.

The alternatives to iron making are generally attempts to avoid the coke making and blast furnace steps by reducing the iron ore with coal in fluidized beds, rotary kilns, or smelters. ${ }^{103-106}$ Most of these processes (compared in Table V) appear to be in the prototype or demonstration plant stages. Projected reductions in carbon are about $30 \%$ per unit of iron produced. These numbers are consistent with Eketorp's analysis of the blast furnace iron making vs. smelting reduction, in which he showed that smelting reduction uses $10-40 \%$ less coal per tonne of iron. ${ }^{108}$

Steelmaking alternatives can be viewed as replacing the electrical energy of EAF melting by using combustion of coal or coke as the heat source for melting scrap; the combustion can also be viewed as replacing some or all of the hot metal energy in the BOF operation. Since about two-thirds of the chemical energy in fossil fuels is lost when electricity is generated, substantial reductions in carbon emissions over the EAF might be expected. As shown in Table $\mathrm{VI}$, this is not the case. Electric furnaces will still emit only one-third to one-half the carbon per tonne of steel produced, compared with the C-FFOX and the $\mathrm{K}(\mathrm{M}) \mathrm{S}$ processes. When charged with $100 \%$ scrap these two alternative processes do offer a significant reduction in carbon emissions (40-60\%) compared with the BOF process. From an operational standpoint, these processes are moreflexible than the BOF, because they can accommodate wide fluctuations in hot metal availability, down to $0 \%$ hot metal. Therefore, as a substitute for the BOF (their original design intent), they would probably help reduce overall carbon emissions, depending on the average fraction of hot metal used.

\section{CONCLUSIONS}

If all of the available steel and aluminum were recycled and substituted for raw ore processing, global carbon emissions would be cut by about $0.15 \%$. But this would be a significant reduction-more than $15 \%$ of the U.S. industry's carbon emissions. It is difficult for any single sector to have a large impact on the global total. (Marland ${ }^{111}$ pointed out that eliminating all the coalfired power plants in the U.S. would only reduce global emissions by $4 \%$.)

The encouraging aspect of the problem is that many technologically and economically sensible approaches to metals production, such as increased recycling, better overall energy efficiency, improved design, and process 
control (so that home scrap production is minimized) will also help to minimize the emission of greenhouse gases.

\section{ACKNOWLEDGEMENTS}

Thanks to Dr. Gregg Marland (OakRidge National Laboratory Carbon Dioxide Information Analysis Center) for providing comments on the manuscript and for recent data on $\mathrm{CO}_{2}$ emissions, to D.F. Anderson (International Iron and Steel Institute) for data on China and the Soviet Union, and to Robert L. Cather for commenting on the manuscript.

\section{Notes and References}

1. National Research Council, Carbon Dioxide and Climate: $A$ Scientific Assessment (Washington, D.C.: National Academy Press, 1979)

2. G.I. Pearman, ed., Carbon Dioxide and Climate: Australian Research, ed. G.I. Pearman (Netley, South Australia: Australian Academy of Science, Griffin Press Ltd., 1980).

3. William W. Kellogg and Robert Schware, Climate Change and Society (Boulderg CO: Westview Press, 1981).

4. William C. Clark, ed. Carbon Dioxide Review 1982 (New York: Oxford University Press, 1982)

5. National Research Council, Changing Climate (Washington, D.C.: National Academy Press, 1983)

6. P.S. Liss and A.J. Crane, Man-Made Carbon Dioxide and Climatic Change (Norwich, England: Geo Books, 1983) 7. W. Bach et al., eds., Carbon Dioxide: Current Views and Developments in Energy/Climate Research (Boston, MA: D. Reide Publishing Co., 1983)

8. John R. Trabalka, ed., Atmospheric Carbon Dioxide and the Global Carbon Cycle, U.S. Dept. of Energy report DOE/ER0239 (December 1985).

9. J.A. Edmonds et al., Future Atmospheric Carbon Dioxide Scenarios and Limitation Strategies (Park Ridge, NJ: Noyes Publications, 1986)

10. Roberto Fantechi and Anver Ghazi, eds., Carbon Dioxide and Other Greenhouse Gases: Climatic and Associated Impacts (Boston, MA: Kluwer Academic Publishers, 1989).

11.Stephen H.Schneider, Global Warming (San Francisco, CA Sierra Club Books, 1989).

12. Stephen H. Schneider, "Climate Modeling," Scientific American, 256 (5) (1987), pp. 78

13. Stephen H. Schneider, "The Changing Climate," Scientific American, 261 (3) (1989), pp. 70-79.

14. J.A. Laurmann, "Future Energy Use and Greenhouse Gas Induced Climatic Warming," in Ref. 10, pp. 101-131.

15. W.M. Post et al., "The Global Carbon Cycle," American Scientist, 78 (4) (1990), pp. 310-326.

16. Ref. 11, p. 28

17. Ref. 15 , p. 313

18. M.A.K. Khalil and R.A. Rasmussen, "Trends of Atmospheric Methane: Past, Present, and Future," in Ref. $10, p .95$ 19. Graph and data by Rotty as shown in Julia A. Watts, "The Carbon Dioxide Question: Data Sampler," in Ref. 4, p. 457

20. Gregg Marland, personal communication (8 October 1990)

21. R.A. Houghton et al., "Carbon Dioxide Exchange Beween the Atmosphere and Terrestrial Ecosystems," in Ref. 8, pp. 113-140.

22. R.M. Rotty and C.D. Masters, "Carbon Dioxide from Fossil Fuel Combustion: Trends, Resources, and Technological Implications," in Ref. 8, p. 70

23. Robert M. White, "The Great Climate Debate," Scientific American, 263 (1) (1990), pp. 37.

24. A. Berger, "Report on Session III: Expected Climatic Change," in Ref. 10, pp. 135-137.

25. Ref. 23, p. 38.
26. Ref. 13, p. 76 .

27. R. Monastersky, "Carbon Dioxide: Where Does It All Go?" Science News, 136 (26 August 1989), p. 132

28 . "CO $\mathrm{CO}_{2}$ Where It Goes, Nobody Knows," Science News, 139 23 March 1991), p. 191

29. Ref. 12, p. 74 .

30. Ref. 5 , pp. $270-284$

31. Ref. 23, p. 40

32. Michael C. MacCracken and Stanley L. Grotch, "The Detection of $\mathrm{CO}_{2}$-Induced Climate Change," in Ref. 10, pp. 175-184

33. Sherwood B. Idso, Carbon Dioxide: Friend or Foe? (Tempe AZ: IBR Press, 1982).

34. Charles P. Alexander, "A Sizzling Scientific Debate Skeptics Claim That the Evidence for Global Warming is Not So Hot," Time, 135 (30 April 1990), p. 84.

35. Richard A. Kerr, "New Greenhouse Report Puts Down

Dissenters," Science, 249 (3 August 1990), p. 481.

36. Ref. 12, p. 77.

37. Ref. 5 , p. 46

38. J.F.B. Mitchell, "Simulation of Climate Change Due to Increases of $\mathrm{CO}^{\prime \prime}$ " in Ref. 10, pp. 144-151.

39. R. Monastersky, "Predictions Drop for Future Sea-Level Rise," Science News, 136 (16 December 1989), p. 397. Rise," Science Nerw,
40. Ref. 23, p. 43.

41. Janet Raloff, "Not All Plants Will Thrive in 'Greenhouse,'” Science News, 136 (26 August 1989), p. 134. 42. R. Monastersky, "Bush Holds Cautious Course on Global Change," Science News, 137 (28 April 1990), p. 263
43. Janet Raloff, "Why the White House Prefers to Wait," Science News, 136 (16 December 1989), p. 395.

44. R. Monastersky, "Buying Time in the War on Global Warming," Science News, 139 (23 March 1991), p. 183. 45. Janet Raloff, "Governments Warm to Greenhouse Action," Science News, 136 (16 December 1989), pp. 394ff.

46. James Burke, "After the Warming," television program 46. James Burke, "After the Warming," television program Maryland Public

47. Ref. 23, p. 42.

48. Joshua M. Epstein and Raj Gupta, "Controlling the Greenhouse Effect," Brookings Occasional Papers (Washing ton, D.C.: Brookings Institution, 1990).

49. Ref. 9 , p. 572.

50. "Salty Farms for Storing Global Carbon," Science News 139 (16 March 1991), p. 175

51. K. Eric Drexler, "Molecular Engineering: An Approach to the Development of General Capabilities for Molecular Manipulation," Proceedings of the National Academy of Sciences, vol. 78 (1981), pp. 5,275-5,278.

52. K. Eric Drexler, "When Molecules Will Do the Work" Smithsonian (November 1982), pp. 145-155

53. K. Eric Drexler, Engines of Creation (New York: Doubleday,

54. K. Eric Drexler, "A Technology of Tiny Things Nanotechnics and Civilization," Whole Earth Review (Spring 1987)

55. K. Eric Drexler, "Nanomachinery: Atomically Precise Gears and Bearings," Proceedings of the IEEE Micro Robots and Teleoperators Workshop (New York: Institute of Electrical and Electronics Engineers, 1987).

56. A. K. Dewdney, “Nanotechnology: Wherein Molecular Computers Control Tiny Circulatory Submarines," Scientific American, 258 (1) (1988), pp. 100-103.

57. K. Eric Drexler, "Rod Logic and Thermal Noise in the Mechanical Nanocomputer," Molecular Electronic Devices, ed. Forrest L. Carter, Ronald Siatkowski, and Hank Wohltjen (New York: Elsevier Science Publishers, 1988), pp. 39-56. 58. K. Eric Drexler, "Exploring Future Technologies," Doing Science, ed. John Brockman (Englewood Cliffs, NJ: Prentice Hall Press, 1991), pp. 73-92.

59. S. David Hu, Handbook of Industrial Energy Conservation (New York: Van Nostrand Reinhold Co., 1983), pp. 227-231. 60. Norman L. Dean, Jr., Energy Efficiency in Industry (Cambridge, MA: Ballinger Publishing Co., 1980), pp. 73-107.

61. Melvin H. Chiogioji, Industrial Energy Conservation (New York: Marcel Dekker, Inc., 1979), p. 567.

62. Ref. 61, pp. 573-574

62. Ref. 61, pp. 573-574.

3. Harold M. Hubbard, "The Real Cost of Energy," Scientific American, 264 (4) (1991), pp. 36-42.

64. Ref. 13, p. 78.

5. Ref. 59 , p. 133

66. José Goldemberg, "How to Stop Global Warming, Technology Review, 93 (8) (1990), pp. 24-31.

67. Stanford Research Institute, Patterns of Energy Consump tion in the United States (Washington, D.C.: Office of Science and Technology, 1972), p. 83.

68. U.S. Dept. of Energy, Annual Energy Review 1989, Energy Information Administration report DOE/EIA-0384(89) (24 May 1990), p. 37.

69. Gregg Marland, "The Impact of Synthetic Fuels on Global Carbon Dioxide Emissions," in Ref. 4, pp. 406-410.

70. U.S. Dept. of Energy, Annual Energy Review 1989, Energy 70. U.S. Dept. of Energy, Annual Energy Review 1989, Energy
Information Administration report DOE/EIA-0384(89) (24 May 1990)

1. Estimated from reconstruction figures in Ref. 15

72. Iron \& Steelmaker, 17 (13) (1990), p. 24

73. Ref. 67, pp. $83 \mathrm{ff}$

74. International Energy Agency, Energy Balances of $O E C D$ Countries 1987-1988 (Paris: OECD/IEA, 1990). Numbers in this reference were divided by the appropriate factor in the appendix to convert from tonnes of oil equivalent and were then multiplied by 0.70 to determine the mass of carbon released from that amount of coal. The 70 percent value was released from that amount of coal. The 70 percent $v$ alu

75. Estimated from 1985 values in Ref. 68, assuming that ferrous and nonferrous metals were consumed in proportion ferrous and nonferrous metals were consumed in proportions values since production levels were also close for those two years.

76. U.S. Dept. of the Interior, Minerals Yearbook 1988, vol. (Washington, D.C.: U.S. Government Printing Office, 1990) Al, p. 109; Cu, p. $310 ; \mathrm{Zn}$, p. 1019

77. U.S. Dept. of Commerce, 1987 Census of Manufacturers Industry Series, "Smelting and Refining of Nonferrous Met als and Alloys" (industries 3331, 3334, 3339, 3341) and "Blast Furnaces, Steel Works, and Rolling and Finishing Mills" (industries 3312, 3313, 3315, 3316, 3317) (1987).

78. R.L. Whiteley and R.E. Storat, "Energy Savings in the Steel Industry" (paper presented at the ASM Conference on Materials for Future Energy Systems, Washington, D.C., 13 May 1984).

79. Jan van Linden, "Aluminum Recycling, From Junkyard to Boardroom," Recycle and Secondary Recovery of Metals, ed. P.R. Taylor, H.Y.Sohn, and N. Jarrett (Warrendale, PA:TMS 1985), pp. 35-45.

80. M.C. Flemings, K.B. Higbie, and D.J. McPherson, Report of Conference on Energy Conservation and Recycling in the Aluminum Industry, conference held at Massachusetts Institute of Technology, Cambridge, MA, 18-20 June 1974.

81. Y. Austin Chang, W.M. Danver, and J.M. Cigan, eds. Energy Useand Conservation in the Metals Industry (New York: The Metallurgical Society of AIME, 1975), pp. 101-120. 82. Allen C. Sheldon, "Energy Use and Conservation in 82. Allen C. Sheldon, "Energy Use and Conse
Aluminum Production," in Ref. 81, pp. 157-171.

Aluminum Production," in Ref. 81, pp. 157-171. ciency of Aluminum Reverbatory Furnaces," in Ref. 81, pp.

84. Richard J. Reed and Robert W. Marshall, “Upgrading
Aluminum Scrap Melter Operation," in Ref. 79, pp. 397-406.

85. V.Subramanian, "Efficiency of Reverberatory Furnaces," Energy Conservation in Industry - Combustion, Heat Recovery and Rankine Cycle Machines, ed.H. Ehringer, G. Hoyaux, and P.A. Pilavachi (Boston, MA: D. Reidel Publishing Company, 1983), pp. 6-20.

86. Ref. 61, p. 224

87. H.H. Kellog, "Melting CathodeCopper-ACaseStudy in Process Energy Efficiency," in Ref. 81, pp. 87-99. 88. Ref. 59, p. 133.

89. Marc H. Ross and Daniel Steinmeyer, "Energy for Industry," Scientific American, 263 (3) (1990), pp. 88-98.

90. R.J. Fruehan, "Scrap in Iron and Steelmaking," in Ref. 79 pp. 13-34

91. H.W. Lownie, Jr., "Potential for Energy Conservation in the Steel Industry," Alternative Energy Sources for the Steel Industry, ed. Julian Szekely (New York: Marcel Dekker, 1977), pp. 99-105.

92. Ref. 61, p. 97

93. International Iron and Steel Institute Committee on Statistics, Statistics on Energy in the Steel Industry 1980-1985 (Brussels, Belgium: IISI, 1987), p. 2

94. D.F. Anderson, private communication (13 June 1991) Data included from The Yearbook of Iron and Steel Industry of China (Beijing, China: Metallurgical Industry Press, 1989). 95. P.F. Chapman and F. Roberts, Metal Resources and Energy (Boston, MA: Butterworths, 1983), p. 138.

96. Ref. 95, pp. 138-139.

97. Charles L. Kusik and Charles B. Kenahan, Energy Use Patterns for Metal Recycling, U.S. Bureau of Mines information circular 8781 (1978)

98. Ref. 95, especially chapters 8 and 11 .

99. Ref. 95 , pp. $180-181$

100. Ref. 95 , pp. 131

101. Ref. 76, p. 112

102 Robert A. Frank, Charles W. Finn, and John F. Elliott,

"Physical Chemistry of the Carbothermic Reduction of Alumina in the Presence of a Metallic Solvent: Part II. Measure ments of Kinetics of Reaction," Met. Trans. B, 20B (1989), p 161.

103. Michiharu Hatano et al., "New Ironmaking Process by Use of Pulverized Coal and

making II, pp. 1049-1055.

104. R. Hauk and J. Flickenschild, "KR-Process Hot Meta Production on the Basis of Coals," in Ref. 103, pp. 1031-1039. 105. W-K. Lu, C. Bryk, and H.Y. Gou, "The LB Furnace for Smelting Reduction of Iron Ores," in Ref. 103, pp. 1031-1039. 106. Franz Oeters and Alpaydin Saatci, "Some Fundamental Aspects of Iron Ore Reduction with Coal," in Ref. 103, pp. Aspects of $1031-1039$.

107. United States Steel Corp., The Making, Shaping and Treating of Steel, 9th ed. (Pittsburgh, PA: Herbick \& Held, 1971), pp. 78-79. Assumes that all of the fixed carbon in the coal is eventually converted to $\mathrm{CO}_{2}$; intermediates are $\mathrm{CH}$ $\mathrm{CO}$, and coke breeze, which are subsequently burned or sintered. The values vary widely (61-84 percent), depending on the mix of low-, medium-, and high-volatile coals and their moisture contents.

108. Sven Eketorp, "Energy Considerations in Reduction Processes," The Future of the World's Steel Industry, ed. Julian Szekely (New York: Marcel Dekker, 1976), pp. $23-43$.

109. R. Kieger and B. Schaffar, "C-FFOX: Steelmaking by Preheating and Oxidizing Melting of Scrap," in Ref. 103, pp. Prop-1082.

110. L.V. Bogdandy et al., "Oxygen Converter Steelmaking with High Scrap Rates," in Ref. 103, pp. 1083-1094. 111. Gregg Marland, private communication (31 October 1990).

\section{Other Sources}

Frost, Paul D., Raymond W. Hale, and Thomas J. McLeer "Energy Consumption in the Primary Production of Metals." Iron and Steel Engineer, 56 (4) (1979), pp. 50-56.

Penner, S.S, and L. Icerman, Demands, Resources, Impact,

Technology, and Policy. Vol. 1 of Energy. 2nd ed. Reading, MA: Addison-Wesley, 1981.

Russell, Clifford S., and William J. Vaughan. Steel Production: Processes, Products, and Residuals. Baltimore, MD: Johns Hopkins University Press, 1976.

Szekely, Julian, ed.The Steel Industry and the Energy Crisis. New York: Marcel Dekker, 1975

U.S. Dept. of the Interior. Energy Perspectives 2. June 1976.

ABOUT THE AUTHORS

David Forrest earned his M.S. in materials science and engineering at Lehigh University 